\title{
Russujaponols G—L, Illudoid Sesquiterpenes, and Their Neurite Outgrowth Promoting Activity from the Fruit Body of Russula japonica
}

\author{
Kazuko Yoshikawa, * Yuki Matsumoto, Hiroshi Hama, Masami Tanaka, Haifeng Zhai, \\ Yoshiyasu FukuYama, Shigenobu Arihara, and Toshihiro Hashimoto \\ Faculty of Pharmaceutical Sciences, Tokushima Bunri University; Yamashiro-cho, Tokushima 770-8514, Japan. \\ Received October 31, 2008; accepted January 5, 2009; published online January 6, 2009
}

\begin{abstract}
Six new illudoid sesquiterpene, russujaponols $G-L(1-6)$ were isolated from the fruit bodies of Russula japonica. Their structures were established primarily by 2D NMR experiments. Furthermore, russujaponols IK showed neurite outgrowth promoting activity in the primary cultured rat cortical neurons.
\end{abstract}

Key words Russula japonica; Russulaceae; illudoid sesquiterpene; russujaponol; neurite outgrowth promoting activity

In the previous paper, ${ }^{1}$ we reported the isolation and structure elucidation of six new illudoid sesquiterpenes, designated as russujaponols $\mathrm{A}-\mathrm{F}$, together with compound $\mathbf{4 b}$ and deliquinone, from the fruit bodies of Russula japonica Hongo (Russulaceae). The chief ingredient, russujaponol A showed the inhibitory activity on migration of human HT1080 fibrosarcoma cell line in vitro. Further purification of the resulting fractions by HPLC gave six new illudoid sesquiterpenes, russujaponols G (1), H (2), I (3), J (4), K (5), and $\mathrm{L}(\mathbf{6})$, together with plorantinone $\mathrm{B}^{2)}$ and epiplorantinone B. ${ }^{3)}$ We describe here the isolation and structure elucidation of $\mathbf{1}-\mathbf{6}$ by various NMR techniques. The structures of $\mathbf{1}-\mathbf{6}$ shown in the Chart 1 are relative configurations. The neurite outgrowth promoting activities ${ }^{4,5)}$ of compounds $3-\mathbf{5}$, epiplorantinone $\mathrm{B}$ and deliquinone were investigated.

Russujaponol G (1) gave a [M] ${ }^{+}$peak at $m / z 252.1720$ on the high-resolution electron ion mass spectrum (HR-EI-MS) which corresponds to a molecular formula $\mathrm{C}_{15} \mathrm{H}_{24} \mathrm{O}_{3}$, requiring four unsaturation equivalents. The IR spectrum of $\mathbf{1}$ showed absorptions at 3385 and $1075 \mathrm{~cm}^{-1}$ due to hydroxy groups. The 15 carbon signals in the ${ }^{13} \mathrm{C}$-NMR spectrum disclosed the signals due to three methyls, four $s p^{3}$ methylenes, one oxymethylene $(\delta 72.6)$, one $s p^{3}$ methine, four $s p^{3}$ quaternary carbons, two of them bearing oxygen function $(\delta 83.6$, 75.1), and two $s p^{2}$ carbons $\left[\delta_{\mathrm{C}} 136.7\right.$ (s), 128.4 (d)] (Table 1). The ${ }^{1} \mathrm{H}-\mathrm{NMR}$ spectrum of 1 certainly exhibited three singlet methyls at $\delta 1.96,1.77$, and 1.62 , one oxymethylene group at $\delta 3.68$ and 3.60 (each d, $J=10.0 \mathrm{~Hz}$ ), and one olefinic proton
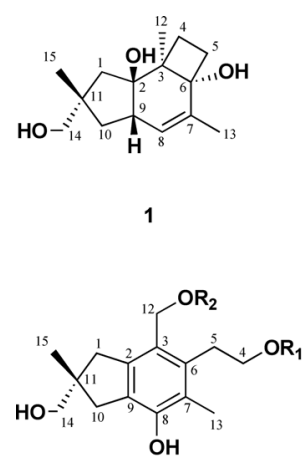

$3: R_{1}=H, R_{2}=M e$
$4: R_{1}=H, R_{2}=E t$ $4: R_{1}=\mathrm{H}, \mathrm{R}_{2}=\mathrm{Et}$
$5: \mathrm{R}_{1}, \mathrm{R}_{2}=\mathrm{Et}$

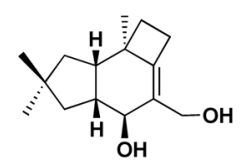

2<smiles>Cc1c(O)c2c(c(O)c1CCO)C[C@@](C)(CO)C2</smiles>

at $\delta 5.37$ (br s) as functional groups. The COSY spectrum revealed the connectivity of isolated ethylene, $\mathrm{H}_{2}-4 / \mathrm{H}_{2}-5, \mathrm{H}-$ $8 / \mathrm{H}-9 / \mathrm{H}_{2}-10$, and an allyl coupling, $\mathrm{H}-8 / \mathrm{H}_{3}-13$ (Fig. 1). These data indicated compound $\mathbf{1}$ was the protoilludene sesquiterpene, ${ }^{1)}$ which satisfied four unsaturation equivalents. Those structure fragments were assembled into a whole structure on the basis of the following heteronuclear multiple bond connectivity (HMBC). The HMBC from $\mathrm{H}_{3}-12(\delta$ $1.77)$ to $\mathrm{C}-2(\delta 83.6), \mathrm{C}-3(\delta$ 50.6), C-4 $(\delta 24.3), \mathrm{C}-6(\delta$ $75.1)$, from $\mathrm{H}_{3}-13(\delta$ 1.96) to $\mathrm{C}-6, \mathrm{C}-7(\delta 136.7), \mathrm{C}-8(\delta$ $128.4)$, from $\mathrm{H}_{3}-15(\delta 1.62)$ to $\mathrm{C}-1(\delta 45.0), \mathrm{C}-10(\delta 42.1)$, $\mathrm{C}-11(\delta 44.3), \mathrm{C}-14(\delta 72.6)$, and from $\mathrm{HO}-2[\delta 5.18(\mathrm{~s})]$ to $\mathrm{C}-1, \mathrm{C}-9(\delta 47.8)$ led to the positions of the two tertiary hydroxy groups at C-2 and C-6, one double bond at C-7, and the primary hydroxy group at $\mathrm{C}-11$ (Fig. 1). The relative configurations of the five successive chiral centers at C-2, C-3, $\mathrm{C}-6, \mathrm{C}-9$, and $\mathrm{C}-11$ in 1 were indicated by the following NOE analyses. The NOEs between H-9 $(\delta$ 2.94)/H-4 $(\delta$ $1.86), / \mathrm{H}-10 \beta(\delta 2.43), \mathrm{H}-10 \beta / \mathrm{H}_{3}-15(\delta 1.62), \mathrm{H}_{3}-15 / \mathrm{H}-1 \beta$ $(\delta 1.84)$, and $\mathrm{H}-1 \alpha(\delta 2.21) / \mathrm{H}_{3}-12(\delta 1.77)$ indicated the $\beta$ cis $\mathrm{A} / \mathrm{B}$ junction, and the $\alpha$-orientations of $\mathrm{HO}-6, \mathrm{H}_{3}-12$, and hydroxymethyl group at C-11 (Fig. 2). On the basis of the above findings, the structure of russujaponol $\mathrm{G}$ was established as $\mathbf{1}$.

Russujaponol H (2) showed a [M] ${ }^{+}$peak at $\mathrm{m} / z 236.1766$ in its HR-EI-MS, indicative of a molecular formula $\mathrm{C}_{15} \mathrm{H}_{24} \mathrm{O}_{2}$, and requiring four unsaturation equivalents as well as 1. The IR spectrum of $\mathbf{2}$ also showed the absorptions at 3430,1080 , and $1060 \mathrm{~cm}^{-1}$ due to hydroxy functions. The

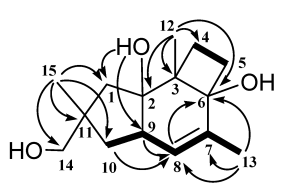

1

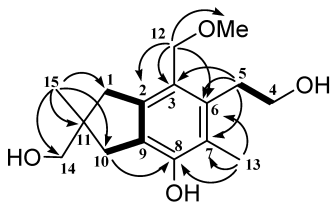

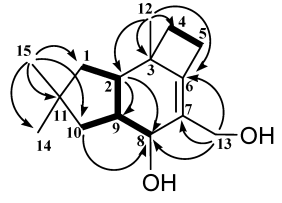

2

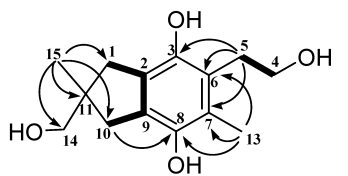

6
Fig. 1. COSY (Bold Line) and Selected HMBC (Arrow Line) of 1, 2, 3, 6 
Table 1. ${ }^{1} \mathrm{H}$ - and ${ }^{13} \mathrm{C}-\mathrm{NMR}$ Assignments for Russujaponols G (1) - $\mathrm{L}(\mathbf{6})$

\begin{tabular}{|c|c|c|c|c|}
\hline \multirow[b]{2}{*}{ Positions } & \multicolumn{2}{|l|}{1} & \multicolumn{2}{|l|}{2} \\
\hline & $\begin{array}{c}{ }^{1} \mathrm{H} \delta \\
\text { (mult. } J \text { in } \mathrm{Hz} \text { ) }\end{array}$ & $\begin{array}{l}{ }^{13} \mathrm{C} \delta \\
\text { (mult.) }\end{array}$ & $\begin{array}{c}{ }^{1} \mathrm{H} \delta \\
\text { (mult. } J \text { in } \mathrm{Hz} \text { ) }\end{array}$ & $\begin{array}{l}{ }^{13} \mathrm{C} \delta \\
\text { (mult.) }\end{array}$ \\
\hline 1 & $\begin{array}{l}1.84(\mathrm{~d}, 13.7) \\
2.21(\mathrm{~d}, 13.7)\end{array}$ & $45.0(t)$ & $1.35(2 \mathrm{H}, \mathrm{m})$ & $41.5(\mathrm{t})$ \\
\hline 2 & & $83.6(\mathrm{~s})$ & $2.38(\mathrm{dd}, 12.6,7.7)$ & $46.6(d)$ \\
\hline 3 & & $50.6(\mathrm{~s})$ & & $45.8(\mathrm{~s})$ \\
\hline 4 & $1.58(\mathrm{~m}), 1.86(\mathrm{~m})$ & $24.3(\mathrm{t})$ & $1.78(2 \mathrm{H}, \mathrm{m})$ & $36.7(\mathrm{t})$ \\
\hline 5 & $2.12(\mathrm{~m}), 2.40(\mathrm{~m})$ & $33.5(\mathrm{t})$ & $2.73(\mathrm{~m}), 2.81(\mathrm{~m})$ & $25.5(\mathrm{t})$ \\
\hline 6 & & $75.1(\mathrm{~s})$ & & $143.5(\mathrm{~s})$ \\
\hline 7 & & $136.7(\mathrm{~s})$ & & $132.2(\mathrm{~s})$ \\
\hline 8 & 5.37 (br s) & $128.4(\mathrm{~d})$ & $4.48(\mathrm{brd}, 8.8)$ & $73.9(\mathrm{~d})$ \\
\hline 9 & $2.94(\mathrm{~m})$ & $47.8(\mathrm{~d})$ & $2.66(\mathrm{~m})$ & $51.5(\mathrm{~d})$ \\
\hline 10 & $\begin{array}{l}2.05(\mathrm{~d}, 12.6) \\
2.43(\mathrm{dd}, 12.6,8.2)\end{array}$ & $42.1(\mathrm{t})$ & $\begin{array}{l}1.31(\mathrm{~m}) \\
2.03(\mathrm{dd}, 12.4,7.4)\end{array}$ & $47.4(\mathrm{t})$ \\
\hline 11 & & $44.3(\mathrm{~s})$ & & $39.6(\mathrm{~s})$ \\
\hline 12 & $1.77(3 \mathrm{H}, \mathrm{s})$ & $17.2(q)$ & $1.05(3 \mathrm{H}, \mathrm{s})$ & $20.3(q)$ \\
\hline 13 & $1.96(3 \mathrm{H}, \mathrm{s})$ & $17.8(\mathrm{q})$ & $\begin{array}{l}4.68,4.72 \\
\quad(\text { each d, 12.4) }\end{array}$ & $59.1(\mathrm{t})$ \\
\hline 14 & $\begin{array}{l}3.60(\mathrm{~d}, 10.0) \\
3.68(\mathrm{~d}, 10.0)\end{array}$ & $72.6(t)$ & $1.06(3 \mathrm{H}, \mathrm{s})$ & $29.4(q)$ \\
\hline \multirow[t]{2}{*}{15} & $1.62(3 \mathrm{H}, \mathrm{s})$ & $28.8(\mathrm{q})$ & $0.96(3 \mathrm{H}, \mathrm{s})$ & $27.2(q)$ \\
\hline & 3 & & 4 & \\
\hline Positions & $\begin{array}{c}{ }^{1} \mathrm{H} \delta \\
\text { (mult. } J \text { in } \mathrm{Hz} \text { ) }\end{array}$ & $\begin{array}{l}{ }^{13} \mathrm{C} \delta \\
\text { (mult.) }\end{array}$ & $\begin{array}{c}{ }^{1} \mathrm{H} \delta \\
\text { (mult. } J \text { in } \mathrm{Hz} \text { ) }\end{array}$ & $\begin{array}{l}{ }^{13} \mathrm{C} \delta \\
\text { (mult.) }\end{array}$ \\
\hline \multirow[t]{2}{*}{1} & $2.97(\mathrm{~d}, 15.4)$ & $42.7(t)$ & $2.97(\mathrm{~d}, 15.4)$ & $42.8(\mathrm{t})$ \\
\hline & $3.44(\mathrm{~d}, 15.4)$ & & $3.42(\mathrm{~d}, 15.4)$ & \\
\hline 2 & & $142.9(\mathrm{~s})$ & & $142.8(\mathrm{~s})$ \\
\hline 3 & & $124.8(\mathrm{~s})$ & & $125.1(\mathrm{~s})$ \\
\hline 4 & $4.14(2 \mathrm{H}, \mathrm{t}, 7.6)$ & $62.8(\mathrm{t})$ & $4.12(2 \mathrm{H}, \mathrm{t}, 7.6)$ & $63.0(\mathrm{t})$ \\
\hline 5 & $3.42(2 \mathrm{H}, \mathrm{t}, 7.6)$ & $34.4(\mathrm{t})$ & $3.40(2 \mathrm{H}, \mathrm{t}, 7.6)$ & $34.4(\mathrm{t})$ \\
\hline 6 & & $137.3(\mathrm{~s})$ & & $137.3(\mathrm{~s})$ \\
\hline 7 & & $122.5(\mathrm{~s})$ & & $122.6(\mathrm{~s})$ \\
\hline 8 & & $152.9(\mathrm{~s})$ & & $152.8(\mathrm{~s})$ \\
\hline 9 & & $126.7(\mathrm{~s})$ & & $126.9(\mathrm{~s})$ \\
\hline \multirow[t]{2}{*}{10} & $2.89(\mathrm{~d}, 15.8)$ & $41.0(\mathrm{t})$ & $2.90(\mathrm{~d}, 15.8)$ & $41.0(\mathrm{t})$ \\
\hline & $3.32(\mathrm{~d}, 15.8)$ & & $3.32(\mathrm{~d}, 15.8)$ & \\
\hline 11 & & $45.2(\mathrm{~s})$ & & $45.2(\mathrm{~s})$ \\
\hline 12 & $4.60(2 \mathrm{H}, \mathrm{s})$ & $70.5(\mathrm{t})$ & $4.60(2 \mathrm{H}, \mathrm{s})$ & $70.0(t)$ \\
\hline 13 & $2.56(3 \mathrm{H}, \mathrm{s})$ & $12.6(\mathrm{q})$ & $2.54(3 \mathrm{H}, \mathrm{s})$ & $12.5(\mathrm{q})$ \\
\hline 14 & $3.77(2 \mathrm{H}, \mathrm{s})$ & $69.9(\mathrm{t})$ & $3.76(2 \mathrm{H}, \mathrm{s})$ & $69.8(\mathrm{t})$ \\
\hline 15 & $1.36(3 \mathrm{H}, \mathrm{s})$ & $25.2(\mathrm{q})$ & $1.36(3 \mathrm{H}, \mathrm{s})$ & $25.3(\mathrm{q})$ \\
\hline OMe or OEt & $3.33(\mathrm{~s})$ & $57.6(\mathrm{q})$ & $\begin{array}{l}1.20(\mathrm{t}, 7.0) \\
3.55(\mathrm{q}, 7.0)\end{array}$ & $\begin{array}{r}15.7(\mathrm{q}) \\
65.5(\mathrm{t})\end{array}$ \\
\hline
\end{tabular}

\begin{tabular}{|c|c|c|c|c|}
\hline \multirow[b]{2}{*}{ Positions } & \multicolumn{2}{|l|}{5} & \multicolumn{2}{|l|}{6} \\
\hline & $\begin{array}{c}{ }^{1} \mathrm{H} \delta \\
\text { (mult. } J \text { in } \mathrm{Hz} \text { ) }\end{array}$ & $\begin{array}{l}{ }^{13} \mathrm{C} \delta \\
\text { (mult.) }\end{array}$ & $\begin{array}{c}{ }^{1} \mathrm{H} \delta \\
\text { (mult. } J \text { in } \mathrm{Hz} \text { ) }\end{array}$ & $\begin{array}{l}{ }^{13} \mathrm{C} \delta \\
\text { (mult.) }\end{array}$ \\
\hline 1 & $\begin{array}{l}2.91(\mathrm{~d}, 15.8) \\
3.34(\mathrm{~d}, 15.8)\end{array}$ & $42.8(\mathrm{t})$ & $\begin{array}{l}2.82(\mathrm{~d}, 15.6) \\
3.28(\mathrm{~d}, 15.6)\end{array}$ & $41.0(\mathrm{t})$ \\
\hline 2 & & $142.9(\mathrm{~s})$ & & $129.9(\mathrm{~s})$ \\
\hline 3 & & $125.1(\mathrm{~s})$ & & $150.1(\mathrm{~s})$ \\
\hline 4 & $3.71(2 \mathrm{H}, \mathrm{t}, 7.0)$ & $71.3(\mathrm{t})$ & $4.47(2 \mathrm{H}, \mathrm{t}, 7.7)$ & $71.2(t)$ \\
\hline 5 & $3.30(2 \mathrm{H}, \mathrm{t}, 7.0)$ & $30.8(\mathrm{t})$ & $2.99(2 \mathrm{H}, \mathrm{t}, 7.7)$ & $29.9(t)$ \\
\hline 6 & & $137.3(\mathrm{~s})$ & & $125.5(\mathrm{~s})$ \\
\hline 7 & & $122.6(\mathrm{~s})$ & & $120.2(\mathrm{~s})$ \\
\hline 8 & & $152.8(\mathrm{~s})$ & & $146.4(\mathrm{~s})$ \\
\hline 9 & & $126.9(\mathrm{~s})$ & & $121.3(\mathrm{~s})$ \\
\hline \multirow[t]{2}{*}{10} & $2.98(\mathrm{~d}, 15.8)$ & $41.0(\mathrm{t})$ & $2.98(\mathrm{~d}, 15.7)$ & $39.9(\mathrm{t})$ \\
\hline & $3.44(\mathrm{~d}, 15.8)$ & & $3.45(\mathrm{~d}, 15.7)$ & \\
\hline 11 & & $45.2(\mathrm{~s})$ & & $46.4(\mathrm{~s})$ \\
\hline 12 & $4.61(2 \mathrm{H}, \mathrm{s})$ & $68.6(t)$ & & \\
\hline 13 & $2.55(3 \mathrm{H}, \mathrm{s})$ & $12.5(\mathrm{q})$ & $2.37(3 \mathrm{H}, \mathrm{s})$ & $13.6(q)$ \\
\hline 14 & $3.77(2 \mathrm{H}, \mathrm{s})$ & $70.0(\mathrm{t})$ & $3.78(2 \mathrm{H}, \mathrm{s})$ & $69.8(\mathrm{t})$ \\
\hline 15 & $1.36(3 \mathrm{H}, \mathrm{s})$ & $25.3(q)$ & $1.36(3 \mathrm{H}, \mathrm{s})$ & $25.1(q)$ \\
\hline \multirow[t]{2}{*}{ OEt } & $\begin{array}{l}1.20(\mathrm{t}, 7.0) \\
3.55(\mathrm{q}, 7.0)\end{array}$ & $\begin{array}{l}15.7(\mathrm{q}) \\
65.5(\mathrm{t})\end{array}$ & & \\
\hline & $\begin{array}{l}1.20(\mathrm{t}, 7.0) \\
3.51(\mathrm{q}, 7.0)\end{array}$ & $\begin{array}{c}15.6(\mathrm{q}) \\
66.6(\mathrm{t})\end{array}$ & & \\
\hline
\end{tabular}

Measurements were performed in $\mathrm{C}_{5} \mathrm{D}_{5} \mathrm{~N}$ at $600 \mathrm{MHz}$ for ${ }^{1} \mathrm{H}$ - and $150 \mathrm{MHz}$ for ${ }^{13} \mathrm{C}$ NMR. ${ }^{13} \mathrm{C}$ multiplicities were established by DEPT pulse sequences.
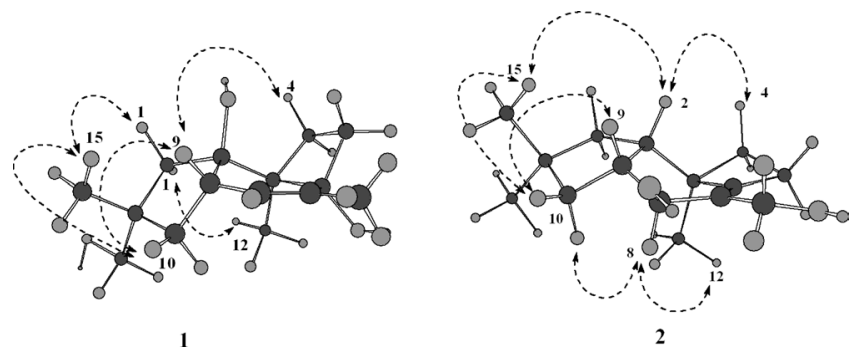

Fig. 2. Selected ROESY (Dashed Arrow Line) of $\mathbf{1}$ and $\mathbf{2}$

${ }^{13} \mathrm{C}-\mathrm{NMR}$ and heteronuclear multiquantum coherence (HMQC) spectra of $\mathbf{2}$ showed three tertiary methyls, two hydroxy groups $\left[\delta_{\mathrm{C}} 73.9(\mathrm{~d}), 59.1(\mathrm{t})\right]$ and one tetrasubstituted double bond $\left[\delta_{\mathrm{C}} 143.5(\mathrm{~s}), 132.2(\mathrm{~s})\right]$ as functional groups. The ${ }^{1} \mathrm{H}-\mathrm{MNR}$ data of 2 showed a close relationship to those of 1 , except for the presence of one oxymethine signal resonated at $\delta 4.48(1 \mathrm{H}$, br d, $J=8.8 \mathrm{~Hz})$ and the absence of the olefinic proton. These data implied that $\mathbf{2}$ is also the protoilludene compound. The COSY correlations could make up the two COSY units, that is, from the oxymethine proton $(\delta$ 4.48, $\mathrm{H}-8) / \mathrm{H}-9 / \mathrm{H}-2 / \mathrm{H}_{2}-1$ and $\mathrm{H}-9 / \mathrm{H}_{2}-10$, and isolated ethylene, $\mathrm{H}_{2}-4 / \mathrm{H}_{2}-5$. Furthermore, HMBC long-range correlations from $\mathrm{H}_{3}-12(\delta 1.05)$ to $\mathrm{C}-2(\delta 46.6), \mathrm{C}-3(\delta 45.8), \mathrm{C}-4(\delta$ $36.7)$, and $\mathrm{C}-6(\delta 143.5)$, and $\mathrm{H}_{3}-15(\delta$ 0.96) to $\mathrm{C}-1(\delta 41.5)$, $\mathrm{C}-10(\delta 47.4), \mathrm{C}-11(\delta 39.6)$, and $\mathrm{C}-14(\delta$ 29.4) led to the connection of the two COSY units. Finally, HMBC correlations from $\mathrm{H}_{2}-13(\delta 4.72,4.68)$ to $\mathrm{C}-6, \mathrm{C}-7$ ( $\left.\delta 132.2\right), \mathrm{C}-8(\delta$ 73.9) could make up the planar structure of 2 (Fig. 1). The relative configurations of the chiral centers in 2 were established by the ROESY experiment. Significant NOE correlations between $\mathrm{H}-2(\delta 2.38) / \mathrm{H}-4(\delta 1.78), / \mathrm{H}_{3}-15(\delta 0.96), \mathrm{H}-$ $9(\delta 2.66) / \mathrm{H}-10 \beta(\delta 2.03), \mathrm{H}-10 \beta / \mathrm{H}_{3}-15, \mathrm{H}-10 \alpha(\delta 1.31) / \mathrm{H}-$ $8(\delta 4.48), \mathrm{H}-8 / \mathrm{H}_{3}-12(\delta 1.05)$ indicated the $\beta$-cis A/B junction, and the $\alpha$-orientations of $\mathrm{H}-8$ and $\mathrm{H}_{3}-12$ (Fig. 2). On the basis of the above findings, the structure of russujaponol $\mathrm{H}$ was established as $\mathbf{2}$

Russujaponol I (3) has the molecular formula $\mathrm{C}_{16} \mathrm{H}_{24} \mathrm{O}_{4}$ in the HR-EI-MS, requiring five unsaturation equivalents. The IR spectrum of $\mathbf{3}$ displayed the presences of the hydroxy group $\left(3430,1080,1070 \mathrm{~cm}^{-1}\right)$ and an aromatic moiety (1620, $\left.1580 \mathrm{~cm}^{-1}\right)$. The ${ }^{13} \mathrm{C}-\mathrm{NMR}$ and HMQC data of $\mathbf{3}$ showed two tertiary methyls $(\delta 25.2,12.6)$, one methoxy $(\delta$ $57.6)$, three primary hydroxyl groups $[\delta 70.5(\mathrm{t}), 69.9(\mathrm{t})$, $62.8(\mathrm{t})]$, and one hexasubstituted benzen ring $[\delta 152.9(\mathrm{~s})$, $\left.142.9(\mathrm{~s}), 137.3(\mathrm{~s}), 126.7(\mathrm{~s}), 124.8(\mathrm{~s}), \delta_{\mathrm{C}} 122.5(\mathrm{~s})\right]$. In the ${ }^{1} \mathrm{H}-\mathrm{NMR}$ spectrum, isolated ethylene signals of the ethylene bridge that was characteristic of $\mathbf{1}$ and $\mathbf{2}$ were not observed. The above data suggested that $\mathbf{3}$ has the illudalane skeleton as russujaponols $\mathrm{E}$ and $\mathrm{F}^{1)}$ Combined analysis of COSY and HMBC spectra enabled assignments of three hydroxylmethyl groups at C-3, C-5 and C-11, and phenolic hydroxy group at $\mathrm{C}-8$ in the illudalane skeleton. Furthermore, the allylic protons $\mathrm{H}_{2}-12$ at $\delta 4.60(2 \mathrm{H}, \mathrm{s})$ showed HMBC correlation to $\mathrm{CH}_{3} \mathrm{O}-(\delta 57.6)$, indicating the methoxy group being placed on the $\mathrm{C}-12$ position (Fig. 1). Based on the above findings and the biosynthsis considerations, the structure of $\mathbf{3}$ was formulated as 6-(2-hydroxyethyl)-2-hydroxymethyl-7-methoxymethyl-2,5-dimethyl-indan-4-ol.

Russujaponol J (4) has the molecular formula $\mathrm{C}_{17} \mathrm{H}_{26} \mathrm{O}_{4}$, 


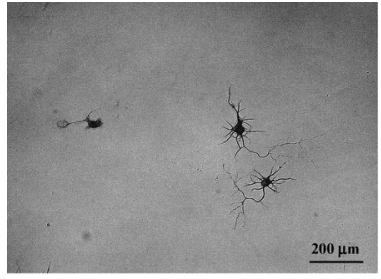

Control (0.5\% EtOH)

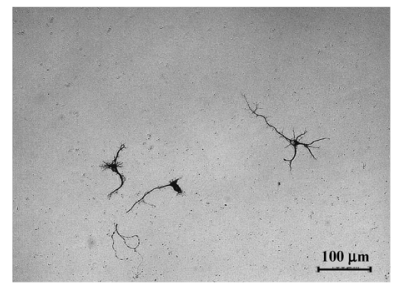

Control (0.5\% EtOH)

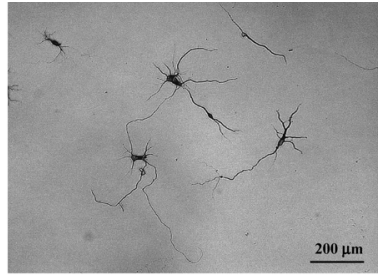

Compound $3(1 \mu M)$

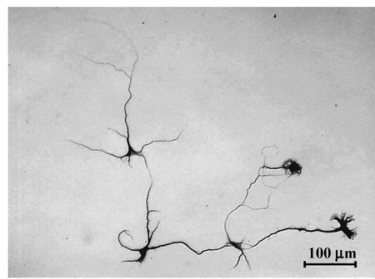

Compound 4 (1 $\mu \mathrm{M})$

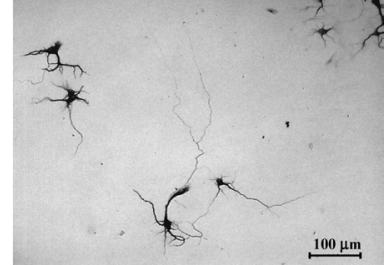

Compound 5 (1 $\mu \mathrm{M})$

Fig. 3. Enhancement of Neurite Outgrowth by $\mathbf{3}-\mathbf{5}$ in Rat Cortical Neuronal Culture

14 mass units more than $\mathbf{3}$, based on the ${ }^{13} \mathrm{C}-\mathrm{NMR}$ data and HR-EI-MS. Analysis of its NMR data with COSY and HMQC showed the presence of the same structure fragments as those of $\mathbf{3}$, such as one hexasubstituted benzen ring, three oxymethylene groups, except for the ethoxy group $\left[\delta_{\mathrm{C}} 15.7\right.$ (q), $\left.65.5(\mathrm{t}), \delta_{\mathrm{H}} 1.20(\mathrm{t}, J=7.0 \mathrm{~Hz}), 3.55(\mathrm{q}, J=7.0 \mathrm{~Hz})\right]$. This finding agreed with the result of MS data. In the HMBC spectrum, the allylic protons $\mathrm{H}_{2}-12$ at $\delta 4.60(2 \mathrm{H}, \mathrm{s})$ showed HMBC correlations to C-2 $(\delta 142.8), \mathrm{C}-3(\delta$ 125.1), C-6 $(\delta$ $137.3)$, and $\mathrm{CH}_{3} \mathrm{CH}_{2} \mathrm{O}-(\delta 65.5)$, indicating the ethoxy group being placed on the $\mathrm{C}-12$ position. Thus, the data above conclusively allowed establishment of structured 4, 7-ethoxymethyl-6-(2-hydroxyethyl)-2-hydroxymethyl-2,5-dimethylindan-4-ol.

Russujaponol K (5) was established $\mathrm{C}_{19} \mathrm{H}_{30} \mathrm{O}_{4}$ by $\mathrm{m} / \mathrm{z}$ $322.2111[\mathrm{M}]^{+}$in the HR-EI-MS as the molecular formula, which was larger than that of $\mathbf{4}$ by $\mathrm{C}_{2} \mathrm{H}_{4} \mathrm{O}$ unit. The ${ }^{1} \mathrm{H}$ - and ${ }^{13} \mathrm{C}$-NMR data of $\mathbf{5}$ were also highly compatible with those of 3 and 4, except for the appearance of the one more ethoxy group $\left[\delta_{\mathrm{C}} 15.6(\mathrm{q}), 66.6(\mathrm{t}), \delta_{\mathrm{H}} 1.20(\mathrm{t}, J=7.0 \mathrm{~Hz}), 3.51(\mathrm{q}\right.$, $J=7.0 \mathrm{~Hz})]$ in the molecule. The HMBC correlations from $\mathrm{H}_{2}-4\left(\delta\right.$ 3.71) to $\mathrm{CH}_{3} \mathrm{CH}_{2} \mathrm{O}-(\delta$ 65.5), and $\mathrm{C}-6(\delta$ 137.3), and from the allylic protons, $\mathrm{H}_{2}-12\left(\delta\right.$ 4.61) to $\mathrm{CH}_{3} \mathrm{CH}_{2} \mathrm{O}-(\delta$ $65.5), \mathrm{C}-2(\delta 142.9), \mathrm{C}-3(\delta 125.1)$, and $\mathrm{C}-6$ revealed the two ethoxyl groups at $\mathrm{C}-4$ and $\mathrm{C}-12$ positions. Thus, the above data conclusively allowed establishment of structured 5, 6-(2ethoxyethyl)-7-ethoxymethyl-2-hydroxymethyl-2,5-dimethylindan-4-ol.

Russujaponol L (6) showed the molecular formula $\mathrm{C}_{14} \mathrm{H}_{20} \mathrm{O}_{4}$ in HR-EI-MS, which was less than that of $\mathbf{3}$ by $\mathrm{C}_{2} \mathrm{H}_{4}$. The ${ }^{1} \mathrm{H}$ - and ${ }^{13} \mathrm{C}$-NMR data of 6 also were highly compatible with those of $\mathbf{3}$, however, the main difference between $\mathbf{6}$ and $\mathbf{3}$ showed the absences of the methoxy and the primary hydroxyl groups in $\mathbf{6}$. The HMBC correlations from allylic protons $\mathrm{H}_{2}-5(\delta 2.99)$ to $\mathrm{C}-3(\delta 150.1), \mathrm{C}-6(\delta 125.5)$, and $\mathrm{C}-7\left(\delta\right.$ 120.2), and the methyl signal $\mathrm{H}_{3}-13(\delta 2.37)$ to $\mathrm{C}-6$, $\mathrm{C}-7$, and $\mathrm{C}-8\left(\delta\right.$ 146.4), $\mathrm{H}_{2}-10(\delta 2.98,3.45)$ to $\mathrm{C}-8$ confirmed the presence of the phenolic hydroxyl group at $\mathrm{C}-3$ in substitution for the methylated primary hydroxyl group in $\mathbf{3}$ (Fig. 1). Thus, the structure of 6 was formulated as 5-(2-hy-

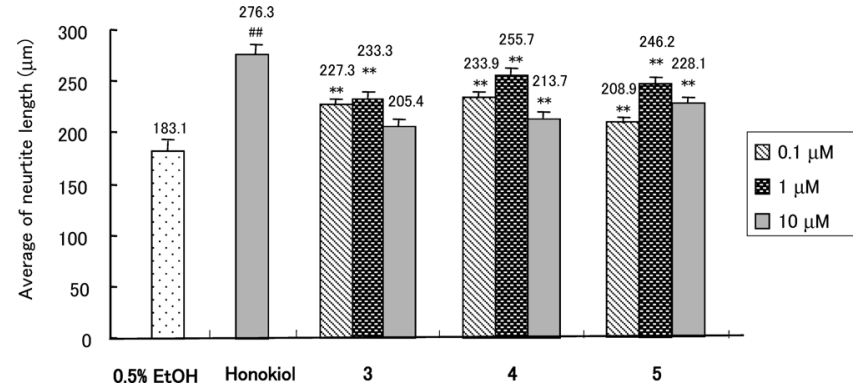

Fig. 4. Morphometric Analysis of the Neurons Effected by $\mathbf{3}-\mathbf{5}$

The data are expressed as means \pm S.E. $(n=80)$; Student's $t$-test: \# $p<0.01$ versus control; Dunnet's $t$-test; **p $<0.01$ versus control.

droxyethyl)-2-hydroxymethyl-2,6-dimethyl-indan-4,7-diol.

The isolated new compounds $3-\mathbf{5}$, with deliquinone, and epiploratinone B were subjected to neurite outgrowth promoting activity in primary neuronal culture. ${ }^{5)}$ Compounds $3-5$ can promote neurite outgrowth of the cultured rat cortical neurons in the range of concentration from 0.1 to $10 \mu \mathrm{M}$ (positive control, honokiol) (Figs. 3, 4). However, deliquinone and epiploratinone B exhibited no efficacy at the same concentration.

\section{Experimental}

General Experimental Procedures Optical rotations were taken on a JASCO DIP-1400 digital polarimeter. IR spectra were measured on a JASCO FT/IR-5300 instrument. UV spectra were recorded with Shimadzu UV-6000 spectrophtometer. NMR spectra were recorded on a Varian UNITY 600 spectrometer. The chemical shifts are given in $\delta(\mathrm{ppm})$ in $\mathrm{C}_{5} \mathrm{D}_{5} \mathrm{~N}$ solution, using tetramethylsilane (TMS) as an internal standard. NMR experiments included ${ }^{1} \mathrm{H}-{ }^{1} \mathrm{H}$ COSY, HMQC, HMBC, and ROESY. Coupling constants ( $J$ values) are given in hertz $(\mathrm{Hz})$. HR-EI-MS were measured on a JEOL JMS-700 MS station. Kiesegel 60 (230 - 400 mesh, Merck) was used for column chromatography, and silica gel 60F-254 (Merck) for TLC. HPLC was carried out on a JASCO-PU 1580 instrument using a COSMOSIL C18 P-MS $(4.6 \times 150 \mathrm{~mm}$ and $20 \times 250 \mathrm{~mm})$ columns.

Fungus Material The fruit bodies of Russula japonica were collected at Tokushima, Japan, in autumn 1999. A voucher specimen (TB3066) is deposited in the Herbarium of Faculty of Pharmaceutical Sciences, Tokushima Bunri University, Tokushima, Japan.

Extraction and Isolation The fresh fruit bodies $(3.8 \mathrm{~kg})$ of $R$. japonica were extracted with $70 \% \mathrm{EtOH}$ at room temperature for 6 weeks. The EtOH extract was partitioned between EtOAc and $\mathrm{H}_{2} \mathrm{O}$. The EtOAc soluble 
portion $(36.0 \mathrm{~g})$ was subjected to silica gel column chromatography with $\left[\left(\mathrm{CH}_{3}\right)_{2} \mathrm{CH}\right]_{2} \mathrm{O}-\mathrm{MeOH}(50: 1-25: 8)$ to afford fractions $1-6$. Fraction 2 was passed through silica gel with $\left[\left(\mathrm{CH}_{3}\right)_{2} \mathrm{CH}\right]_{2} \mathrm{O}-\mathrm{MeOH}-\mathrm{H}_{2} \mathrm{O}(25: 1: 0$ $25: 2: 0.1)$ to afford fractions $2-1-4$. Fractions $2-2$ and $2-4$ were purified by preparative HPLC (deverosil PE, $30-35 \% \mathrm{MeOH}$, flow rate $8 \mathrm{ml} / \mathrm{min}$ )) to afford russujaponols $\mathrm{H}(\mathbf{2}, 6.0 \mathrm{mg})$ and $\mathrm{L}(\mathbf{6}, 4.1 \mathrm{mg})$ from fraction 2-2, deliquinone $(\mathbf{8}, 20.0 \mathrm{mg})$ from fraction $2-4$, respectively. Fraction 5 was passed through silica gel with $\left.\left[\left(\mathrm{CH}_{3}\right)_{2} \mathrm{CH}\right]_{2} \mathrm{O}-\mathrm{MeOH}-\mathrm{H}_{2} \mathrm{O}(25: 2: 0-25: 6: 0.1)\right]$ to afford fractions $5-1-4$. Similar purification by silica gel column chromatography and preparative HPLC (deverosil $\mathrm{PE}, 30 \% \mathrm{MeOH}$, flow rate $8 \mathrm{ml} / \mathrm{min})$ ) afford russujaponols $\mathrm{I}(\mathbf{3}, 13.0 \mathrm{mg}), \mathrm{J}(\mathbf{4}, 12.5 \mathrm{mg}), \mathrm{K}(\mathbf{5}$, $16.5 \mathrm{mg})$, and compound $5 \mathrm{a}(7,33.6 \mathrm{mg})$ from fraction $5-2$ and russujaponols $\mathrm{G}(\mathbf{1}, 3.5 \mathrm{mg})$ from fraction 5-3.

Russujaponol G (1): Amorphous powder; $[\alpha]_{\mathrm{D}}^{25}-26.4^{\circ}(c=0.3, \mathrm{MeOH})$; FT-IR (dry film) $\mathrm{cm}^{-1}: 3385,1075,1035 ;{ }^{1} \mathrm{H}-$ and ${ }^{13} \mathrm{C}$-NMR see Table 1; HR-EI-MS $m / z$ [M] $]^{-} 252.1720$ (Calcd for $\mathrm{C}_{15} \mathrm{H}_{24} \mathrm{O}_{3}, 252.1725$ ).

Russujaponol H (2): Amorphous powder; $[\alpha]_{\mathrm{D}}^{25}-19.9^{\circ}(c=0.6, \mathrm{MeOH})$; FT-IR (dry film) $\mathrm{cm}^{-1}: 3430,1080,1060 ;{ }^{1} \mathrm{H}-$ and ${ }^{13} \mathrm{C}-\mathrm{NMR}$ see Table $1 ;$ HR-EI-MS $m / z[\mathrm{M}]^{+} 236.1766$ (Calcd for $\mathrm{C}_{15} \mathrm{H}_{24} \mathrm{O}_{2}, 236.1776$ ).

Russujaponol I (3): Amorphous powder; $[\alpha]_{\mathrm{D}}^{25}-17.7^{\circ}(c=0.3, \mathrm{MeOH})$; FT-IR (dry film) $\mathrm{cm}^{-1}: 3370,1620,1580,1455,1080,1070$; UV $\lambda_{\text {max }}$ $(\mathrm{MeOH}) \mathrm{nm}(\log \varepsilon): 217$ (4.90), 236 (4.57), 288 (4.57); ${ }^{1} \mathrm{H}-$ and ${ }^{13} \mathrm{C}-\mathrm{NMR}$ see Table 1; HR-EI-MS $m / z[M]^{+} 280.1669$ (Calcd for $\mathrm{C}_{16} \mathrm{H}_{24} \mathrm{O}_{4}, 280.1674$ ).

Russujaponol J (4): Amorphous powder; $[\alpha]_{\mathrm{D}}^{25}-30.8^{\circ}(c=0.4, \mathrm{MeOH})$; FT-IR (dry film) $\mathrm{cm}^{-1}: 3370,1620,1575,1455,1080,1070$; UV $\lambda_{\max }$ $(\mathrm{MeOH}) \mathrm{nm}(\log \varepsilon): 217$ (4.90), 236 (4.57), 288 (4.57); ${ }^{1} \mathrm{H}-$ and ${ }^{13} \mathrm{C}-\mathrm{NMR}$ see Table 1; HR-EI-MS $m / z[M]^{+} 294.1830$ (Calcd for $\mathrm{C}_{17} \mathrm{H}_{26} \mathrm{O}_{4}, 291.1572$ ).

Russujaponol K (5) ${ }^{6}$ : Amorphous powder; $[\alpha]_{\mathrm{D}}^{25}+6.23^{\circ}(c=2.7, \mathrm{MeOH})$; FT-IR (dry film) $\mathrm{cm}^{-1}: 3370,1620,1580,1460,1080,1070$; UV $\lambda_{\max }$ $(\mathrm{MeOH}) \mathrm{nm}(\log \varepsilon): 210$ (4.29), 228 (3.88), 256 (3.39); ${ }^{1} \mathrm{H}-$ and ${ }^{13} \mathrm{C}-\mathrm{NMR}$ see Table 1; HR-EI-MS $m / z[M]^{+} 322.2111$ (Calcd for $\mathrm{C}_{19} \mathrm{H}_{30} \mathrm{O}_{4}, 322.2145$ ).

Russujaponol L (6): Amorphous powder; $[\alpha]_{\mathrm{D}}^{25}-5.5^{\circ}(c=0.6, \mathrm{MeOH})$; FT-IR (dry film) $\mathrm{cm}^{-1}: 3370,1620,1575,1460,1080,1070$; UV $\lambda_{\max }$ $(\mathrm{MeOH}) \mathrm{nm}(\log \varepsilon): 217$ (4.90), 236 (4.57), 288 (4.57); ${ }^{1} \mathrm{H}-$ and ${ }^{13} \mathrm{C}-\mathrm{NMR}$ see Table 1; HR-EI-MS $m / z[M]^{+} 252.1360$ (Calcd for $\mathrm{C}_{14} \mathrm{H}_{20} \mathrm{O}_{4}, 252.1362$ ).

Neurotrophic Bioassay Neuronal cells were separated from the cere- bral hemispheres of a fetal $18 \mathrm{~d}$ SD rat (Japan SLC, Inc.) and suspended in $10 \% \mathrm{FAB} / \mathrm{MEM}$, then seeded at 12000 cells $/ \mathrm{cm}^{2}$ into poly-L-lysine-coated 24-well cultured plates. After $48 \mathrm{~h}$, the medium was changed to a serum-free medium, neurobasal medium (NBM) supplemented with B27, in the presence or absence of the compounds at $0.1,1.0$, and $10 \mu \mathrm{M}$. After incubation for $5 \mathrm{~d}$, the cells were fixed with $4 \%$ paraformaldehyde/PBS for anti-MAP-2 immunohistochemical stain. The neurite outgrowths affected by samples were analyzed under a microscope and photographs taken with 200 magnifications (Fig. 3). The neurite outgrowths affected by sample as an average of neurite length were analyzed under microscope. Eighty numbers of neurons, which did not grow on or near glial cells and madno network-formation to more than two cells, and were well stained with anti-MAP-2, were selected for measurements of each sample. Length of the longest neurite extended from a cell body was measured and calculated by using Lumina Vision and MacSCOPE software (Fig. 4).

Acknowledgments We are grateful to Mr. T. Ohashi, fungologist, Tokushima Prefectural Tomioka Nishi High School, for confirming the identification of fungus and to Ms. Ohashi for gathering the fungus.

\section{References and Notes}

1) Yoshikawa K., Kaneko A., Matsumoto Y., Hama H., Arihara S., J. Nat. Prod., 69, 1267-1270 (2006).

2) Clericuzio M., Fu J., Pan F., Pang Z., Sterner O., Tetrahedron, 53, 9725-9740 (1997).

3) Clericuzio M., Han F., Pan F., Pang Z., Sterner O., Acta Chem. Scand., 52, 1333-1337 (1998).

4) Huang J.-M., Yokoyama R., Yang C.-S., Fukuyamam Y., J. Nat. Prod., 63, 514-516 (2000).

5) Fukuyama Y., Nakade K., Minoshima Y., Yokoyama R., Zhai H., Mitsumoto, Y., Bioorg. Med. Chem. Lett., 12, 1163-1166 (2002).

6) Russujaponol K (5) has positive $[\alpha]_{D}$ value whereas other similar compounds 3,4 , and $\mathbf{6}$ have negative $[\alpha]_{D}$ values. It is thought that this result depend on the purity of $\mathbf{5}$, which was checked by TLC (diisopropyl ether- $\mathrm{MeOH}-\mathrm{H}_{2} \mathrm{O}=25: 3: 0.1$ ) and HPLC (deverosil PE, 37\% $\mathrm{MeOH})$. 